\title{
Ten years of lung cancer in a single center: gender, histology, stage and survival
}

\author{
Regina Gironés, Pedro López, Rebeca Chulvi, Mamen Cañabate, Torregrosa M. Dolores \\ Medical Oncology Unit, LluísAlcanyís Hospital, 46800 Xàtiva, Spain.
}

Correspondence to: Dr. Regina Gironés, Medical Oncology Unit, LluísAlcanyís Hospital, CrtaXàtiva a Silla km 2, 46800 Xàtiva, Valencia, Spain. E-mail: girones_reg@gva.es

\section{A B S T R A C T}

Aim: The aim was to describe, in a prospective manner, the clinical, histopathological and epidemiological characteristics of lung cancer patients who attended as outpatients at the Lluís Alcanyís, Xàtiva Medical Oncology Hospital, València, Spain from January 2004 to July 2014. We also analyzed survival and compared our data with that reported in the literature. Methods: Clinical and demographic characteristics were analyzed for the entire series and trends were compared by year of diagnosis. Changes in epidemiology were examined and compared. Results: There were 701 patients $(91.4 \%$ were men, mean age 67.6$)$. Main histology was squamous cell carcinoma $(41.5 \%)$. Squamous cell carcinoma prevailed in men $(45.5 \%)$ and adenocarcinoma (ADC) in women $(60.3 \%)$. The percentage of men with lung cancer and of patients with squamous cell carcinoma was higher than in the reported worldwide data and remained throughout the 10 years period. Mean survival was low, with $<10 \%$ survivors at 5 years. Stage of disease remained the main prognostic factor for survival. Conclusion: Squamous cell carcinoma continues to be the most frequent histological type in our area. Male and smoking is associated with lung carcinoma while ADC more often occurs in females. Over the time, our epidemiological and histological patterns have not changed, possibly in relation to maintenance of smoking habits.

Key words: Epidemiology, histology, lung cancer, smoking, survival

\section{Introduction}

Epidemiological changes in smoking habits are affecting the pattern of lung cancer patients, with perhaps an increasing number of non-smokers, women involved, and variation in the occurrence of adenocarcinoma (ADC). ${ }^{[1-3]}$ Despite treatment advances in lung cancer, it continues to be one of the most lethal cancers worldwide.

Lung cancer still ranks as the leading cause of tumor-related death in the world. ${ }^{[1]}$ Some important epidemiological factors are age, gender and histology, and these have markedly changed in the past few years. ${ }^{[4]}$ Reasons could be non-smoking policies, population aging, women now smoking, improvement in histological and imaging diagnosis, etc. ${ }^{[2-6]}$ The patterns of change vary, mainly given the heterogeneity of smoking habits in different countries. There is scattered information available concerning the various epidemiological and clinical aspects of lung cancer today, especially in Spain and in daily clinical practice. ${ }^{[7]}$ In order to describe how lung cancer patients

\section{Access this article online}

Quick Response Code:

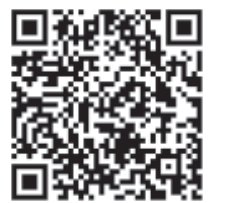

Website:

www.jcmtjournal.com

DOI:

10.4103/2394-4722.166971 are managed at our regional hospital, since 2004, all such patients who were seen at our outpatient oncology unit were prospectively registered into a hospital-based cancer registry. The aim of the present review is to describe their epidemiologic characteristics, focusing on gender, histology and stage. Trends through years were also analyzed.

The primary objective was to describe the lung cancer characteristics of patients followed for up to 10 years, from 2004 to 2014, and to study the evolution of the disease over these years. In addition, we herein describe their epidemiologic characteristics, correlations, and prognostic factors through these years.

\section{Methods \\ Patients and methods}

This was a single-center study, prospectively performed at the Medical Oncology Unit of our hospital. All

This is an open access article distributed under the terms of the Creative Commons Attribution-NonCommercial-ShareAlike 3.0 License, which allows others to remix, tweak, and build upon the work non-commercially, as long as the author is credited and the new creations are licensed under the identical terms.

For reprints contact: reprints@ @medknow.com

How to cite this article: Gironés R, López $P$, Chulvi R, Cañabate M, Dolores TM. Ten years of lung cancer in a single center: gender, histology, stage and survival. J Cancer Metastasis Treat 2015;1:201-7.

Received: 15-12-2014; Accepted: 20-07-2015. 
patients seen by our medical consultation (not all with a diagnosis of lung cancer) were prospectively included in our database registry. During the study period, our hospital served a predominantly rural community, with a population of about 210,000 in which geographic mobility was low. Our lung cancer medical unit treated and monitored patients by the same oncologist. Candidates for surgery and radiotherapy were referred to other hospitals for treatment, as our hospital does not offer this specialty.

From the records of patients who attended during the study period (2004-2014), the following information was gathered: date of diagnosis, age at appointment, gender and tumor histology (2004 WHO classification). ${ }^{[8]}$ Immunohistochemical markers (CK7, CK20, TTF-1 and p63) have been used at our hospital since 2007. ${ }^{[9-11]}$ Tumor-node-metastasis (TNM) stage by American Joint Committee on Cancer, Seventh Edition, was also utilized. ${ }^{[12]}$ Patients with non-small cell lung cancer (NSCLC) were classified by clinical parameters (clinical TNM), with small cell lung cancer (SCLC) also being classified by TNM system. Dates of death were included, although when the date was undefined based on records, family was contacted. We reported the cause of death (death without disease; death with the disease). For patients still alive, the last follow-up was recorded as July 15, 2014. Survival time was calculated from the time of histological/radiological diagnosis. Patients had to have at least 1-month of follow-up.

Genetic testing, when performed, was for the epidermal growth factor receptor (EGFR) and other NSCLC-driving mutations. Screening for drug-sensitive EGFR mutations was conducted as part of a clinical assistance program, since June 2010, by peptide nucleic acid-locked nucleic acid polymerase chain reaction clamp-based testing. Those who were not analyzed have been recorded as "not determined." Anaplastic lymphoma kinase (ALK) translocations were determined via fluorescence in situ hybridization since June 2012. We did not study K-RAS mutations as part of the standard of care. Other aspects relevant to prognosis, such as the Eastern Cooperative Oncology Group score, treatment type, weight loss and smoking habits, were not recorded.

\section{Statistical analysis}

Results were expressed as means (standard deviation) and percentages. The relationships between different variables were evaluated. Statistics of contrasts, such as Chi-square, Mann-Whitney $U$-test or Kruskal-Wallis $H$-test, were used for comparisons of two variables. Estimations are accompanied by $95 \%$ confidence intervals. Statistical significance was set at a value of $P<0.05$. Survival time was defined as the period from the date of first visit to the date of mortality or last follow-up. Survival date was updated on July 15, 2014. In addition to the estimation of the survival rates by Kaplan-Meier method, patients were classified into groups for comparison of their demographic and clinical characteristics as follows: gender, stage and histology. The same classification was made for comparison of survival by year of diagnosis. Statistical analysis was performed using SPSS 12.

\section{Study approval}

The institution's ethical review board approved the study, and all patients provided written informed consent and gave permission before study entry to collect their clinical data for scientific purposes and publication.

\section{Results}

From January 1, 2004 to June 15, 2014, 701 patients were included at our series. Patients' characteristics are shown in Table 1. We found an aged and male-predominant population (mean age: 67.6 ; $91.4 \%$ were male).

Table 1: Patient characteristics $(n=701)$

\begin{tabular}{|c|c|}
\hline Characteristics & $n(\%)$ \\
\hline \multicolumn{2}{|l|}{ Gender } \\
\hline Men & $642(91.6)$ \\
\hline Women & $59(8.4)$ \\
\hline \multicolumn{2}{|l|}{ Age, years } \\
\hline Mean, range & $67.6(34-94)$ \\
\hline Median & 69 \\
\hline Mode & 70 \\
\hline \multicolumn{2}{|l|}{ Histology } \\
\hline Unconfirmed & $24(3.4)$ \\
\hline Small cell & $120(17.1)$ \\
\hline Non-small cell & $556(79.4)$ \\
\hline Squamous & $291(41.5)$ \\
\hline Adenocarcinoma & $187(26.7)$ \\
\hline Bronchoalveolar & $1(0.1)$ \\
\hline Large cell carcinoma & $43(6.1)$ \\
\hline Carcinoma not typed & $15(2.1)$ \\
\hline Sarcoma-squamous (carcinosarcoma) & $3(0.4)$ \\
\hline Neuroendocrine tumors & $11(1.6)$ \\
\hline Mesothelioma & $6(0.9)$ \\
\hline \multicolumn{2}{|l|}{ Stage at diagnosis } \\
\hline 0 & $1(0.1)$ \\
\hline I & $71(10.1)$ \\
\hline II & $53(7.6)$ \\
\hline III & $171(24.4)$ \\
\hline IV & $405(57.8)$ \\
\hline \multicolumn{2}{|l|}{ Survival (months) } \\
\hline Mean, range & $25.58(22.1-29)$ \\
\hline Median & 11 \\
\hline \multicolumn{2}{|l|}{ Situation at last follow-up (July 15, 2014) } \\
\hline Alive without disease & $42(6)$ \\
\hline Alive with disease & $115(16.4)$ \\
\hline Death without disease & $23(3.3)$ \\
\hline Death with disease & $521(74.3)$ \\
\hline \multicolumn{2}{|l|}{ Situation at last follow-up (July 15, 2014) } \\
\hline Alive & $157(22.4)$ \\
\hline Death & $544(77.6)$ \\
\hline
\end{tabular}




\section{Trends in gender by years}

Only $59(8.4 \%)$ patients were women [Figure 1]. This low incidence was maintained across the years. We found a slight increase in women patients from 2010 to $2014(P=0.045)$. A ratio of almost $9: 1$ was maintained across the years. Female was related to younger age $(P=0.001)$, histology (ADC and small cell: $P=0.001)$, Stage IV $(P=0.02)$ [Table 2].

\section{Distribution by histological type}

Histology related to smoking habit (SCLC and squamous cell lung cancer [SQCLC]) was predominated (121, 17.2\% SCLC and 291, 41.5\% SQCLC) [Table 1].

\section{Histologic trends by years}

Trends through years showed a decline in SQCLC. Although it was the main histology (incidence 37-45\%), in later years, we found a significant increase in ADC (32-40\%) and a significant and relevant increase in SCLC (last date near 20-25\%) $(P=0.0001)$ [Figure 2].

\section{Stage trends by years}

A tendency of an increase of earlier stages in the last years is shown in Figure $3(P=0.063)$. There was also a decrease in Stage IV and an increase of Stage III patients. Stage was related to gender (female and Stage IV, $P=0.024$ ). For histology and stage, we found a relationship $(P=0.03)$ between squamous cell and Stage III and between ADC and Stage IV. When we studied correlations between stages

Table 2: Comparison between men and women

\begin{tabular}{|c|c|c|c|}
\hline & $\begin{array}{l}\text { Male } n(\%): \\
633(90.3 \%)\end{array}$ & $\begin{array}{c}\text { Female: } n(\%): \\
68(9.7 \%)\end{array}$ & $\begin{array}{c}\text { Chi-square } \\
\text { Pearson }\end{array}$ \\
\hline \multicolumn{4}{|l|}{ Age, years } \\
\hline Mean (range) & $68(34-94)$ & $63.3(34-88)$ & $P=0.000$ \\
\hline Median & 70 & 61 & \\
\hline Mode & 70 & 48 & \\
\hline \multicolumn{4}{|l|}{ Histology, $n(\%)$} \\
\hline Unconfirmed & $23(3.6)$ & $1(1.5)$ & $P=0.000$ \\
\hline Small cell & $109(17.2)$ & $10(14.7)$ & \\
\hline \multicolumn{4}{|l|}{ Non-small cell } \\
\hline Squamous & $288(45.5)$ & $4(5.9)$ & \\
\hline Adenocarcinoma & $146(23.1)$ & $41(60.3)$ & \\
\hline Bronchoalveolar & 0 & $1(1.5)$ & \\
\hline Large cell carcinoma & $39(6.2)$ & $4(5.9)$ & \\
\hline Carcinoma not typed & $9(1.4)$ & $6(8.8)$ & \\
\hline $\begin{array}{l}\text { Sarcoma-squamous } \\
\text { (carcinosarcoma) }\end{array}$ & $3(0.5)$ & 0 & \\
\hline $\begin{array}{l}\text { Neuroendocrine } \\
\text { tumors }\end{array}$ & $10(1.6)$ & $1(1.5)$ & \\
\hline Mesothelioma & $6(0.9)$ & 0 & \\
\hline \multicolumn{4}{|l|}{ Stage at diagnosis } \\
\hline 0 & 0 & $1(0.6)$ & $P=0.02$ \\
\hline I & $66(10.4)$ & $7(10.3)$ & \\
\hline II & $48(7.6)$ & $4(5.9)$ & \\
\hline III & $162(25.6)$ & $8(11.8)$ & \\
\hline IV & $357(56.4)$ & $49(71.4)$ & \\
\hline
\end{tabular}

and histology, we found more early stage patients with NSCLC $(P=0.015)$. SCLC was related to the advanced stage. Genetic testing for EGFR and other NSCLC-driving mutations was performed only for Stage IV patients, with only EGFR and $A L K$ being analyzed. Only ADC had EGFR-activating mutations (4\% of all ADC, 3.2\% all NSCLC, Stage IV). Female ADC was related to EGFR mutation (11 patients, $36 \%$ of women). Only $1.7 \%$ of ADC in men had EGFR mutations. No patients in our series had $A L K$ rearrangement.

\section{Overall survival}

Survival time was ascertained for all patients. Median overall survival (OS) for the entire series was

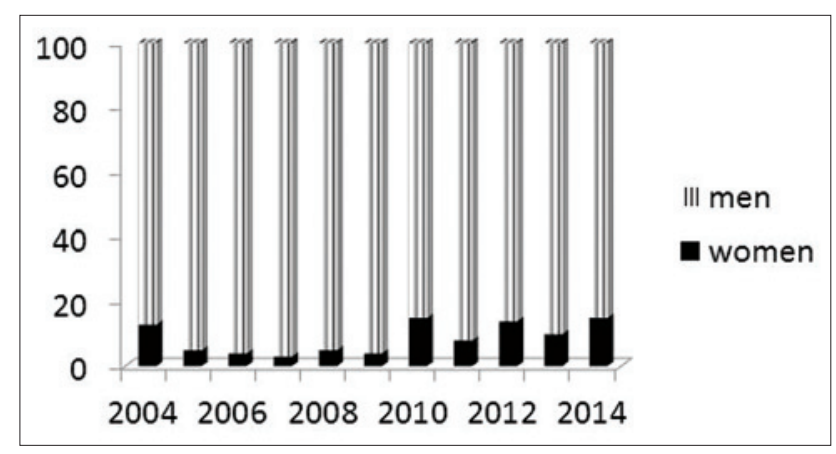

Figure 1: Trends in gender by year

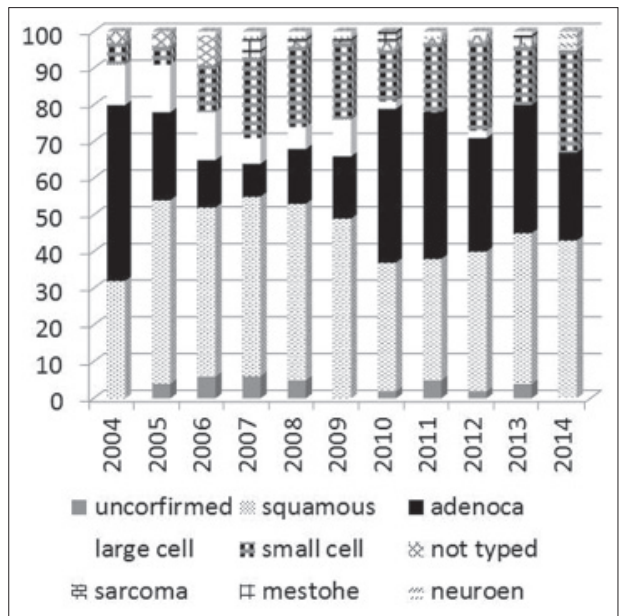

Figure 2: Trends in histology by year

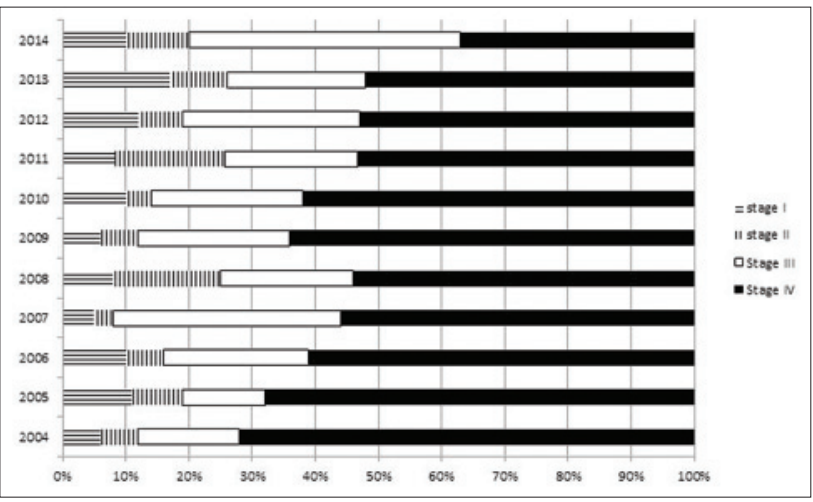

Figure 3: Stage trends by years 
25.5 months (22-29) [Figure 4]. At last follow-up, $22.4 \%$ of patients were alive and $77.6 \%$ were deceased. There were $6.1 \%$ (43) alive without disease, $16.5 \%$ (115) alive with disease, 3.3\% (23) were dead without disease and 74.1\% (520) were dead from lung cancer. The only significant prognostic factor for OS was stage $(P=0.000)$. Stage was a predictive factor for better survival and remained significant through all years. It shows OS by stage [Figure 5]. Histology was unrelated to survival by stages, except for Stage IV $(P=0.003)$. Through the years, survival for Stages I and II decreased, it maintained for Stage III, and had an increase of 2 months for Stage IV [Figure 6]. As death by other cause is important for OS, we analyzed causes of death. Only for Stages I (26.8\%) and II $(5.8 \%)$ there were deaths without disease. For Stages III and IV, lung cancer was the main cause of dead for all patients. Gender and histology were only related to survival for Stage IV. Women with ADC and neuroendocrine differentiation had better survival $(P=0.021)$, while men with squamous cell carcinoma had better survival $(P=0.044)$, both groups in Stage IV. Also, molecular prognostic factors, in particular, mutated EGFR was related to better survival for Stage IV (17.3 [10.3-24.3] months $v s$. 10.4 [9-11] months; $P=0.02$ ) but when we analyzed females, there was no difference in survival with women with $E G F R$-mutated vs. wild type or unknown ADC (EGFR-mutated [16.7 months] $v s$. wild type or unknown [14.8 months, $P=0.54])$.

\section{Longer survival for Stage IV}

Median OS for Stage IV patients was nearly 12 months and there were 100 patients with median OS of 12 months or more in this stage $(24.6 \%)$. Median OS for those with $<12$ months was only 5 months (4.6-5.3). For those surviving more than 1-year, OS was 26.5 months (23-30 range) $(P=0.0000)$. Prognostic factors related to longer survival with Stage IV were: female $(P=0.000)$, histology (ADC and neuroendocrine), and EGFR mutation for men only. Longer survival was statistically significant, related to the year of diagnosis (2011 and 2012, $P=0.006)$.

\section{Discussion}

After the analysis of our 10 years database, we have found that lung cancer in our region remains a disease of smoker men. The predominant cause of lung cancer in men is active cigarette smoking. From our date, we cannot check the hypothesis that women are more susceptible than men to smoking-induced lung cancer. What we have found is that young women are smokers and elderly are non-smoker lung cancer patients. However, aspects of lung cancer in men and women continue to indicate potential male and female differences in the etiology of lung cancer, which based on several observations. Among non-smokers, women have higher lung cancer incidence rates than men. There are different clinical characteristics of lung cancer in women compared with men, such as the higher percentage of ADC in non-smokers, the greater prevalence of EGFR gene mutations in ADCs among non-smokers, and better prognosis. Our study reports on the variation in lung cancer patterns and trends across 10 years in a single center registry. ${ }^{[13-16]}$ Special attention has been given to gender, histology, stage and survival. We found a high incidence of lung cancer in men that maintained across the years. The majority of patients were diagnosed at an advanced stage and OS remained

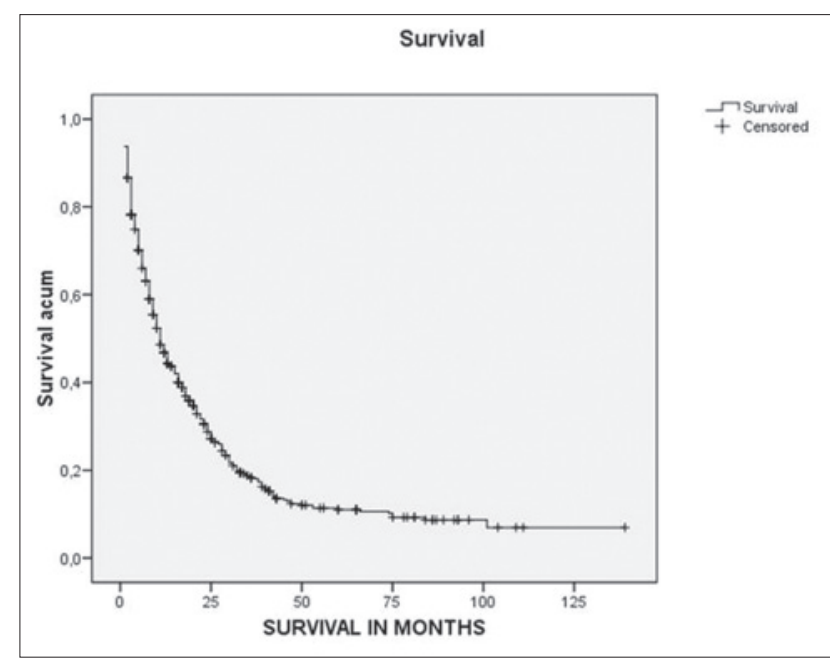

Figure 4: Overall survival for all the series

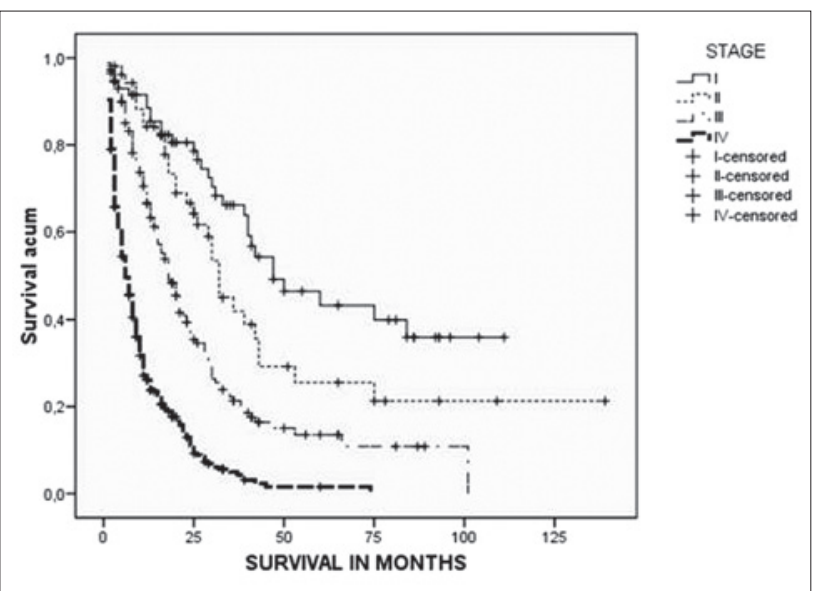

Figure 5: Overall survival by stages

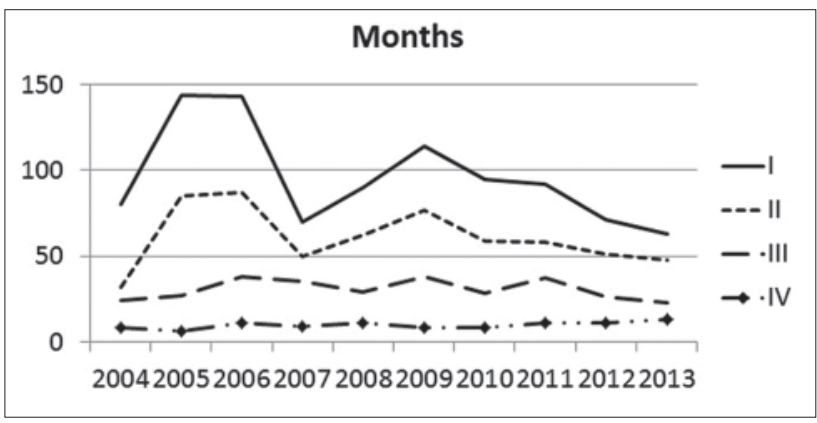

Figure 6: Evolution of median survival for stages across the years 
poor for all the series. Stage was the main prognostic factor for survival.

The predominance of lung cancer men in our series has been reported yet in Spain. ${ }^{[17-20]}$ The current male-to-female ratio in the USA is close to one. ${ }^{[21,22]}$ Our ratio of males to females with lung cancer is still high, ${ }^{[23-25]}$ similar to other spainish rural areas. In any case, the male-to-female ratio is still substantially higher in Spain (8.5 in 2003) ${ }^{[26,27]}$ than in other Western countries, where it varies between 1.3 and 4.5 likely due to the much more rare habit of smoking in women than in men. ${ }^{[2,4,28]}$ It is known that over $95 \%$ of Spanish male lung cancer patients smoke. ${ }^{[3]}$ Anti-tobacco policies had been introduced in Spain only in recent years. ${ }^{[20,28]}$ So, the reason for the predominance of male patients in our area could be explained by tobacco use. We have not specified tobacco habits of our series, but almost $90 \%$ were likely current or former smokers. ${ }^{[29]}$ There is a popular type of manufactured cigar, named "caliqueño," without filter, and not low-tar so that smokers maintained the profile of tobacco users (not inhaling deeper, so generating central tumors, as squamous and small cell cancers).

In our rural area, in the non-smoking population, the incidence of lung cancer is higher among women. ${ }^{[30]}$ For lung cancer women, those elderly, always non-smokers, developed ADC. The younger female patients, usually smokers, developed lung cancer related to smoke, such as SCLC. Recent findings also suggest that women may be somewhat more susceptible to the carcinogenic effect of tobacco, ${ }^{[6,31]}$ although this remains a matter of debate.

Respect to histology, in our area we found a predominance of squamous and small cell cancer through the years. This distribution is different from those worldwide. Worldwide, the trend is toward an increase in the proportion of adeno- and a decrease in squamous cell carcinomas, although the rate of change varies across different geographical areas. ${ }^{[18]}$ This change has mainly been attributed to the decline in the number of smokers and the more widespread consumption of filtered cigarettes in USA. In spite of the proportional decline over the last 20-30 years, squamous cell carcinoma is still the most common histological subtype among males in several European countries $37 \%$ in France, $44 \%$ in Poland and $45 \%$ in Holland). ${ }^{[5]}$ In Spain, squamous cell carcinoma is the most common subtype with percentages varying between $24 \%$ and $50 \%$ in local and regional registries and SCLC still accounts for some $20 \%$ of cases in most Spanish registries. In United States, ADC $(40 \%)$ is the most common subtype, followed by squamous cell carcinoma (25\%) and large cell carcinoma $(10 \%) .^{[26]}$ Incorporation of women into tobacco use worldwide and smoking filtered cigarettes that are low in nicotine could partially explain the rise in the rate of ADC worldwide. ${ }^{[28,32]} \mathrm{We}$ found a relationship between histology and gender as squamous and small cell cancers prevailed in males and ADC in females. In our series as in most series, Stage IV remained the most common stage. ${ }^{[26]}$ However, our series distribution by stage has changed through the years, with a decrease in Stage IV and increase in Stage III. We have not implemented yet the lung cancer screening. We can not explain this tendency change on stage across years.

OS for our entire series remained low. Overall 5-year survival rate for all stages of lung cancer, is $17 \%$ worldwide. $^{[27]}$ Our 5-year OS for all series was $15 \%$ and the only factor related to survival was stage. For Stage IV, a median increase of 2 months was seen through years with a better prognosis in the latest years. When we analyzed Stage IV patients, we found a double distribution. Those who did not survive more than 12 months had a median OS of only 5 months. Although long survival in lung cancer has been described and is a matter of interest, shorter survival patients are still more common and should be a matter of study to know why there are so many patients with this discouraging OS. For long survival at our database, the main factor was a molecular prognostic factor (EGFR mutation). There was an interaction between female gender, ADC histology and EGFR mutation, as women with ADC were nearly all mutated. Our series had a low percentage of patients with $E G F R$ activating mutations. However, most patients had not been tested for EGFR status. Probably, the low rate of men with ADC EGFR mutations (only 1.7\%) could be explained by the high rate of smoking habit in this population.

Our work has some weak points. Despite the importance of a long follow-up time, our work is not as accurate as it could have been. In fact, first we presented a hospital-based cancer registry of outpatient service; therefore a selection bias could not be excluded. Population-based cancer registries should be preferred. However, in Spain, in spite of many efforts ${ }^{[17-20]}$ not more than $26 \%$ of the Spanish population $(28 \%$ in the case of childhood cancer) is covered by cancer registries and the distribution of them is not random. ${ }^{[22]}$ Second, we have not considered other prognostic factors, such as performance status or treatment. Thus, we must be cautious with conclusions. Treatment could be one of the explanations of why women with ADC had no differences on survival depending on EGFR status. In our country, lung cancer patients have access to EGFR TKI on the second and third line, regardless on $E G F R$ status. ${ }^{[33]}$ and most of these patients may have received $E G F R$ TKI. Despite this bias and weaknesses, we believe on the value of having own clinical real date if all admit that cancer is an individual disease, and probably, lung cancer is different according to epidemiology characteristics. 


\section{Conclusion}

This single center analysis suggests that at least at our region, lung cancer remains a men disease and tobacco-related cancer. Advances and improvements on OS seemed to have been achieved only in those tumors unrelated to smoking (non-smoker women EGFR mutated patients). Efforts to reduce tobacco use and carry on with improvement in treatment could modify this disappointing survival for our patients.

\section{Financial support and sponsorship}

Nil.

\section{Conflicts of interest}

There are no conflicts of interest.

\section{References}

1. Ferlay J, Soerjomataram I, Dikshit R, Eser S, Mathers C, Rebelo M, Parkin DM, Forman D, Bray F. Cancer incidence and mortality worldwide: sources, methods and major patterns in GLOBOCAN 2012. Int J Cancer 2015;136:E359-86.

2. Weir HK, Thun MJ, Hankey BF, Ries LA, Howe HL, Wingo PA, Jemal A, Ward E, Anderson RN, Edwards BK. Annual report to the nation on the status of cancer, 1975-2000, featuring the uses of surveillance data for cancer prevention and control. J Natl Cancer Inst 2003;95:1276-99.

3. Bach PB, Kattan MW, Thornquist MD, Kris MG, Tate RC, Barnett MJ, Hsieh LJ, Begg CB. Variations in lung cancer risk among smokers. J Natl Cancer Inst 2003;95:470-8.

4. Janssen-Heijnen ML, Coebergh JW. The changing epidemiology of lung cancer in Europe. Lung Cancer 2003;41:245-58.

5. Alberg AJ, Brock MV, Samet JM. Epidemiology of lung cancer: looking to the future. J Clin Oncol 2005;23:3175-85.

6. Thomas L, Doyle LA, Edelman MJ. Lung cancer in women: emerging differences in epidemiology, biology and therapy. Chest 2005;128:370-81.

7. Sánchez de Cos Escuín J, Disdier Vicente C, Corral Peñafiel J, Riesco Miranda JA, Sojo González MA, Masa Jiménez JF. Overall long-term survival in lung cancer analyzed in 610 unselected patients. Arch Bronconeumol 2004;40:268-74.

8. Travis WD, Brambilla E, Müller-Hermelink HK, Harris CC. Pathology and Genetics of Tumours of the Lung, Pleura, Thymus and Heart. Lyon: IARC Press; 2004.

9. Cadioli A, Rossi G, Costantini M, Cavazza A, Migaldi M, Colby TV. Lung cancer histologic and immunohistochemical heterogeneity in the era of molecular therapies: analysis of 172 consecutive surgically resected, entirely sampled pulmonary carcinomas. Am J Surg Pathol 2014;38:502-9.

10. Choy B, Findeis-Hosey JJ, Li F, McMahon LA, Yang Q, $\mathrm{Xu} \mathrm{H}$. High frequency of coexpression of maspin with p63 and p53 in squamous cell carcinoma but not in adenocarcinoma of the lung. Int J Clin Exp Pathol 2013;6:2542-7.

11. Montezuma D, Azevedo R, Lopes P, Vieira R, Cunha AL, Henrique R. A panel of four immunohistochemical markers (CK7, CK20, TTF-1 and p63) allows accurate diagnosis of primary and metastatic lung carcinoma on biopsy specimens. Virchows Arch 2013;463:749-54.

12. Goldstraw P, Crowley J, Chansky K, Giroux DJ, Groome PA, Rami-Porta R, Postmus PE, Rusch V, Sobin L. The IASLC Lung Cancer Staging Project: proposals for the revision of the TNM stage groupings in the forthcoming (seventh) edition of the TNM Classification of malignant tumours. J Thorac Oncol 2007;2:706-14.

13. Gironés R, Torregrosa D, Gómez-Codina J, Maestu I, Tenias JM, Rosell R. Lung cancer chemotherapy decisions in older patients: the role of patient preference and interactions with physicians. Clin Transl Oncol 2012;14:183-9.

14. Gironés R, Torregrosa D, Gómez-Codina J, Maestu I, Tenias JM, Rosell R. Prognostic impact of comorbidity in elderly lung cancer patients: use and comparison of two scores. Lung Cancer 2011;72:108-13.

15. Gironés R, Torregrosa D, Díaz-Beveridge R. Comorbidity disability and geriatric syndromes in elderly breast cancer survivors. Results of a single-center experience. Crit Rev Oncol Hematol 2010;73:236-45.

16. Gironés R, Torregrosa D, Maestu I, Gómez-Codina J, Tenias JM, Costa RR. Comprehensive Geriatric Assessment (CGA) of elderly lung cancer patients: a single-center experience. J Geriatr Oncol 2012;3:98-103.

17. Santos-Martínez MJ, Curull V, Blanco ML, Macià F, Mojal S, Vila J, Broquetas JM. Lung cancer at a university hospital: epidemiological and histological characteristics of a recent and historical series. Arch Bronconeumol 2005;41:307-12.

18. Sánchez de Cos Escuín J, Miravet Sorribes L, Abal Arca J, Núñez Ares A, Hernández Hernández J, Castañar Jover AM, Muñoz Gutiérrez FJ, García Arangüena L, Alonso MA, Montero Martínez MC, Allende González J, Sánchez Hernández I. The EpicliCP-2003 study: a multicenter epidemiological and clinical study of lung cancer in Spain. Arch Bronconeumol 2006;42:446-52.

19. Miravet L, Peláez S, Paradís A, Arnal M, Cabadés F. Epidemiological study of lung cancer in the northern part of the province of Castellón. Arch Bronconeumol 2001;37:298-301.

20. Hernández IS, Alonso JL, Sánchez CA. Epidemiology of lung cancer in Spain and forecast for the future. Arch Bronconeumol 2006;42:594-9.

21. National Cancer Institute. Non-Small Cell Lung Cancer Treatment $\left(\mathrm{PDQ}{ }^{\circledR}\right)$ : General Information About Non-Small Cell Lung Cancer (NSCLC). Available from: http:/www. cancer.gov/cancertopics/pdq/treatment/non-small-cell-lung/ healthprofessional. [Last accessed on 2011 Nov 07].

22. American Cancer Society. Cancer Facts and Figures. Atlanta: American Cancer Society; 2013.

23. Salmerón D, Chirlaque MD, Isabel Izarzugaza $M$, Sánchez MJ, Marcos-Gragera R, Ardanaz E, Galceran J, Mateos A, Navarro C. Lung cancer prognosis in Spain: the role of histology, age and sex. Respir Med 2012;106:1301-8.

24. Navarro C, Martos C, Ardanaz E, Galceran J, Izarzugaza I, Peris-Bonet R, Martínez C; Spanish Cancer Registries Working Group. Population-based cancer registries in Spain and their role in cancer control. Ann Oncol 2010;21:iii3-13.

25. Montero C, Rosales M, Otero I, Blanco M, Rodríguez G, Peterga S, Pita S, Verea H. Lung cancer in the health care area of A Coruña (Spain): incidence, clinical approach and survival. Arch Bronconeumol 2003;39:209-16.

26. Alonso-Fernández MA, García-Clemente M, Escudero-Bueno C; Grupo ASTURPAR (Sociedad Asturiana de Patología del Aparato Respiratorio) del Cáncer del Pulmón (GACP). Characteristics of lung cancer in a region in northern Spain. Arch Bronconeumol 2005;41:478-83.

27. Hernández-Hernández JR, Heras-Gómez F, Cordovilla-Pérez MR, Antolín-García T, Bollo De Miguel E; Grupo de Estudio CB07-SOCALPAR. Incidence of bronchopulmonary cancer in Castilla y Leon and Cantabria in the year 2007. A study by the Castilla y Leon and Cantabria Respiratory Diseases Society (SOCALPAR). Arch Bronconeumol 2010;46:7-14. 
28. Lortet-Tieulent J, Soerjomataram I, Ferlay J, Rutherford M, Weiderpass E, Bray F. International trends in lung cancer incidence by histological subtype: adenocarcinoma stabilizing in men but still increasing in women. Lung Cancer 2014;84:13-22.

29. Gironés Sarrió R, Torregrosa MD, López P, Gómez-Codina J, Rosell R. Smoking habits in elderly lung cancer patients: still no changes in epidemiology? A single-center experience. Clin Transl Oncol 2010;12:686-91.

30. Subramanian J, Govindan R. Lung cancerin never smokers: a review. J Clin Oncol 2007;25:561-70.

31. Henschke CL, Yip R, Miettinen OS. Women's susceptibility to tobacco carcinogens and survival after diagnosis of lung cancer. JAMA 2006;296:180-4.

32. Gray N. The consequences of the unregulated cigarette. Tob Control 2006;15:405-8.

33. Shepherd FA, Rodrigues Pereira J, Ciuleanu T, Tan EH, Hirsh V, Thongprasert S, Campos D, Maoleekoonpiroj S, Smylie M, Martins R, van Kooten M, Dediu M, Findlay B, Tu D, Johnston D, Bezjak A, Clark G, Santabárbara P, Seymour L; National Cancer Institute of Canada Clinical Trials Group. Erlotinib in previously treated non-small-cell lung cancer. $N$ Engl J Med 2005;353:123-32. 